\title{
ANALISIS PENERIMAAN SISTEM COMPUTER BASED TEST (CBT) DENGAN MENGGUNAKAN TECHNOLOGY ACCEPTANCE MODEL (TAM) (STUDI KASUS SMKN 1 BANJARMASIN)
}

\author{
1. STKIP PGRI Banjarmasin \\ kentiyuliana@stkipbjm.ac.id \\ 2. SMK Unggulan Husada Banjarmasin
}

Kenti Yuliana $^{1}$ dan Siti Suhaimah ${ }^{2}$

\begin{abstract}
ABSTRAK
Penelitian ini bertujuan untuk mengetahui penerimaan pengguna terhadap sistem Computer Based Test (CBT) dengan model Technology Acceptance Model (TAM) berdasarkan lima konstruk. Kelima konstruk tersebut adalah Kemudahan Pengguna Persepsian (Perceived Ease Of Use/PEOU), Kegunaan Persepsian (Perceived Usefulness/PU), Sikap terhadap Perilaku (Attitude Towards Behavior/ATB), Minat Perilaku (Behavioral Intention/BI) dan Penggunaan Sesungguhnya (Actual Use/AU). Tingkat signifikan yang digunakan dalam penelitian ini adalah 5\% dengan nilai $t_{\text {tabel }} 1,96$ yang didapatkan dari proses bootstrapping yang berasumsi memiliki Derajat Kebebasan (DK) sebesar 500. Berdasarkan hasil analisis data, diperoleh hasil sebagai berikut: (1) Konstruk kemudahan penggunaan persepsian berpengaruh terhadap konstruk kegunaan persepsian sebesar 69\%; (2) Konstruk kemudahan penggunaan persepsian berpengaruh terhadap konstruk sikap terhadap perilaku sebesar 38\%; (3) Konstruk kegunaan persepsian berpengaruh terhadap konstruk sikap terhadap perilaku sebesar 47\%; (4) Konstruk kegunaan persepsian berpengaruh terhadap konstruk minat perilaku sebesar 29\%; (5) Konstruk kegunaan persepsian berpengaruh terhadap konstruk penggunaan sesungguhnnya sebesar 19\%; (6) Konstruk sikap terhadap perilaku berpengaruh terhadap konstruk minat perilaku sebesar 46\%; dan (7) Konstruk minat perilaku berpengaruh terhadap konstruk penggunaan sesungguhnya sebesar $59 \%$.
\end{abstract}

Kata kunci: Analisis, Technology Acceptance Model (TAM), Computer Based Tes (CBT), Partial Least Squares (PLS)

\section{A. Latar Belakang}

\section{PENDAHULUAN}

Sekolah Menengah Kejuruan (SMK) merupakan salah satu lembaga pendidikan yang bertujuan untuk mempersiapkan lulusannya menjadi tenaga kerja yang mempunyai pengetahuan dan keterampilan tingkat menengah sesuai dengan bidangnya. Misi utama SMK adalah untuk mempersiapkan peserta didik sebagai calon tenaga kerja yang memiliki kesiapan untuk memasuki dunia usaha/industri. Selain itu, SMK merupakan salah satu bentuk pendidikan formal yang bertujuan untuk mempersiapkan peserta didik agar dapat bekerja di perusahaan. SMK tidak hanya memberi materi secara teori, tetapi juga memberikan materi keterampilan yang 
akan menjadi bekal bagi pelaku pendidikan untuk memasuki persaingan dunia usaha/industri yang semakin kompetitif.

Peraturan Pemerintah (PP) Nomor 29 Tahun 2005 merumuskan bahwa Pendidikan Menengah Kejuruan mengutamakan penyiapan siswa untuk memasuki lapangan kerja serta mengembangkan sikap profesional. Hal ini sejalan dengan tujuan dan misi SMK sebagai wadah pendidikan yang mempersiapkan peserta didik untuk terjun ke dunia kerja.

Ujian akhir merupakan penilaian pencapaian kompetensi peserta didik selama mengikuti proses pembelajaran di satuan pendidikan. Penggunaan komputer dalam ujian atau yang biasa disebut dengan Computer Based Test (CBT) memudahkan pelaksana untuk membuat soal beragam dengan mengkombinasikan beberapa paket soal. Menurut Rosdiana (2008) Computer Based Test (CBT) merupakann tes/evaluasi yang diselenggarakan dengan menggunakan komputer. Karakteristik dari tes ini sama dengan tes konvensional yaitu menggunakan satu perangkat tes untuk beberapa peserta dengan panjang tes yang sama. Perbedaannya terletak pada teknik penyampaian butir soal yang tidak lagi menggunakan kertas, baik untuk naskah soal maupun lembar jawaban. Sistem koreksi langsung dilakukan oleh Komputer.

Berdasarkan uraian di atas, pemanfaatan teknologi informasi di SMK Negeri 1 Banjarmasin salah satunya yaitu Ujian Akhir Sekolah Berbasis Komputer (UASBK) atau biasa dikenal dengan Computer Based Test (CBT). Sejak pelaksanaan dari tahun 2013/2014 hingga sekarang, sistem CBT memiliki kelebihan yakni sangat memudahkan tim pelaksana atau panitia UASBK dalam pelaksanaan ujian, untuk soal UASBK yang dilaksanakan adalah satu mata pelajaran dalam satu hari yang dibagi menjadi beberapa kelompok atau sesi membuat siswa tidak terlalu terbebani dengan mata pelajaran lain yang biasanya dalam pelaksanaan ujian tertulis dalam satu hari dilakukan ujian dua sampai tiga mata pelajaran. Pelaksanaan UASBK juga memberikan pengalaman kepada para siswa dalam penggunaan komputer terkait Computer Based Test (CBT).

Salah satu teori tentang penggunaan sistem teknologi informasi yang dianggap sangat berpengaruh dan umumnya digunakan untuk menjelaskan penerimaan individual terhadap penggunaan sistem teknologi informasi adalah model penerimaan teknologi (Technology Acceptance Model atau TAM). Berdasarkan kelebihannya yakni, Technology Acceptance Model (TAM) telah diuji dengan banyak penelitian dan hasilnya sebagian besar mendukung dan menyimpulkan bahwa Technology Acceptance Model (TAM) merupakan model yang baik. Bahkan, Technology Acceptance Model (TAM) telah banyak diuji dibandingkan dengan model yang lain misalnya dengan Theory Reasoned Action (TRA) dan Theory Planned Behavior (TPB) dan hasilnya juga konsisten bahwa Technology Acceptance Model (TAM) cukup baik. Berdasarkan pernyataan tersebut, peneliti tertarik menggunakan model Technology Acceptance Model (TAM) pada penelitian ini.

\section{B. Rumusan Masalah}

1. Apakah kemudahan penggunaan persepsian (perceived ease of use) berpengaruh terhadap kegunaan persepsian (perceived usefulness) dalam penerimaan Computer Based Test (CBT)? 
2. Apakah kemudahan penggunaan persepsian (perceived ease of use) berpengaruh terhadap sikap terhadap perilaku (attitude towards behavior) dalam penerimaan Computer Based Test (CBT)?

3. Apakah kegunaan persepsian (perceived usefulness) berpengaruh terhadap sikap terhadap perilaku (attitude towards behavior) dalam penerimaan Computer Based Test (CBT)?

4. Apakah kegunaan persepsian (perceived usefulness) berpengaruh terhadap minat perilaku (behavioral intention) dalam penerimaan Computer Based Test (CBT)?

5. Apakah kegunaan persepsian (perceived usefulness) berpengaruh terhadap penggunaan sesungguhnya (actual use) dalam penerimaan Computer Based Test (CBT)?

6. Apakah sikap terhadap perilaku (attitude towards behavior) berpengaruh terhadap minat perilaku (behavioral intention) dalam penerimaan Computer Based Test (CBT)?

7. Apakah minat perilaku (behavioral intention) berpengaruh terhadap penggunaan sesungguhnya (actual use) dalam penerimaan Computer Based Test (CBT)?

\section{Batasan Masalah}

1. Sistem yang dianalisis dalam penelitian ini adalah sistem Computer Based Test (CBT), dengan menggunakan Technology Acceptance Model (TAM).

2. Variabel yang digunakan adalah Kegunaan Persepsian (Perceived Usefulness/PU), Kemudahan Persepsian (Perceived Ease of Use/PEOU), Sikap Terhadap Perilaku (Attitude Towards Behavior/ATB), Minat Perilaku (Behavioral Intention/BI), dan Penggunaan Sesungguhnya (Actual Use/AU).

3. Responden penelitian ini ialah siswa kelas X dan XI SMKN 1 Banjarmasin yang telah melaksanakan Ujian Akhir Sekolah Berbasis Komputer (UASBK) atau yang biasa disebut Computer Based Test (CBT).

\section{Tujuan Penelitian}

1. Mengetahui pengaruh kemudahan penggunaan persepsian (perceived ease of use) terhadap kegunaan persepsian (perceived usefulness) dalam penerimaan Computer Based Test (CBT).

2. Mengetahui pengaruh kemudahan penggunaan persepsian (perceived ease of use) terhadap sikap terhadap perilaku (attitude towards behavior) dalam penerimaan Computer Based Test (CBT).

3. Mengetahui pengaruh kegunaan persepsian (perceived usefulness) terhadap sikap terhadap perilaku (attitude Towards behavior) dalam penerimaan Computer Based Test (CBT).

4. Mengetahui pengaruh kegunaan persepsian (perceived usefulness) terhadap minat Perilaku (behavioral intention) dalam penerimaan Computer Based Test (CBT).

5. Mengetahui pengaruh kegunaan persepsian (perceived usefulness) terhadap penggunaan sesungguhnya (actual use) dalam penerimaan Computer Based Test (CBT). 
6. Mengetahui pengaruh sikap terhadap perilaku (attitude towards behavior) terhadap minat perilaku (behavioral intention) dalam penerimaan Computer Based Test (CBT).

7. Mengetahui minat perilaku (behavioral intention) terhadap penggunaan sesungguhnya (actual use) dalam penerimaan Computer Based Test (CBT).

\section{E. Hipotesis}

1. H1 : Kemudahan penggunaan persepsian (perceived ease of se) berpengaruh terhadap kegunaan persepsian (perceived usefulness) dalam penerimaan Computer Based Test (CBT).

2. H2 : Kemudahan penggunaan persepsian (perceived ease of use) berpengaruh terhadap sikap terhadap perilaku (attitude towards behavior) dalam penerimaan Computer Based Test (CBT).

3. H3 : Kegunaan persepsian (perceived usefulness) berpengaruh terhadap sikap terhadap perilaku (attitude towards behavior) dalam penerimaan Computer Based Test (CBT).

4. H4 : Kegunaan persepsian (perceived usefulness) berpengaruh terhadap minat perilaku (behavioral intention) dalam penerimaan Computer Based Test (CBT).

5. H5 : Kegunaan persepsian (perceived usefulness) berpengaruh terhadap penggunaan sesungguhnya (actual use) dalam penerimaan Computer Based Test (CBT).

6. H6 : Sikap terhadap perilaku (attitude towards behavior) berpengaruh terhadap minat perilaku (behavioral intention) dalam penerimaan Computer Based Test (CBT).

7. H7 : Minat perilaku (behavioral intention) berpengaruh terhadap penggunaan sesungguhnya (actual use) dalam penerimaan Computer Based Test (CBT).

\section{METODE PENELITIAN}

\section{A. Jenis Penelitian}

Jenis penelitian yang digunakan dalam penelitian ini adalah eksplanasi (explanatory) yang bertujuan untuk menganalisis hubungan-hubungan antara satu variabel dengan variabel yang lain.

\section{B. Populasi dan Sampel}

Populasi dalam penelitian ini adalah seluruh siswa kelas X dan XI SMKN 1 Banjarmasin pada tahun ajaran 2017/2018 sebanyak 1056 siswa. Sampel dalam penelitian ini sebanyak 290 siswa, ditentukan menggunakan teknik solvin.

\section{Deskripsi Responden}

Kuesioner disebar sebanyak 290 responden pengguna Computer Based Test (CBT) kelas X dan XI semua jurusan. Responden jurusan Bisnis Daring dan Pemasaran (BDP) sebanyak 40, responden jurusan Otomatisasi dan Kelola Perkantoran (OKP) sebanyak 60, responden jurusan Teknik Komputer dan Jaringan 
sebanyak 34, responden jurusan Multimedia (MM) sebanyak 94, responden jurusan Akuntansi dan Keuangan Lembaga (AKL) sebanyak 62.

\section{Tahapan Penelitian}

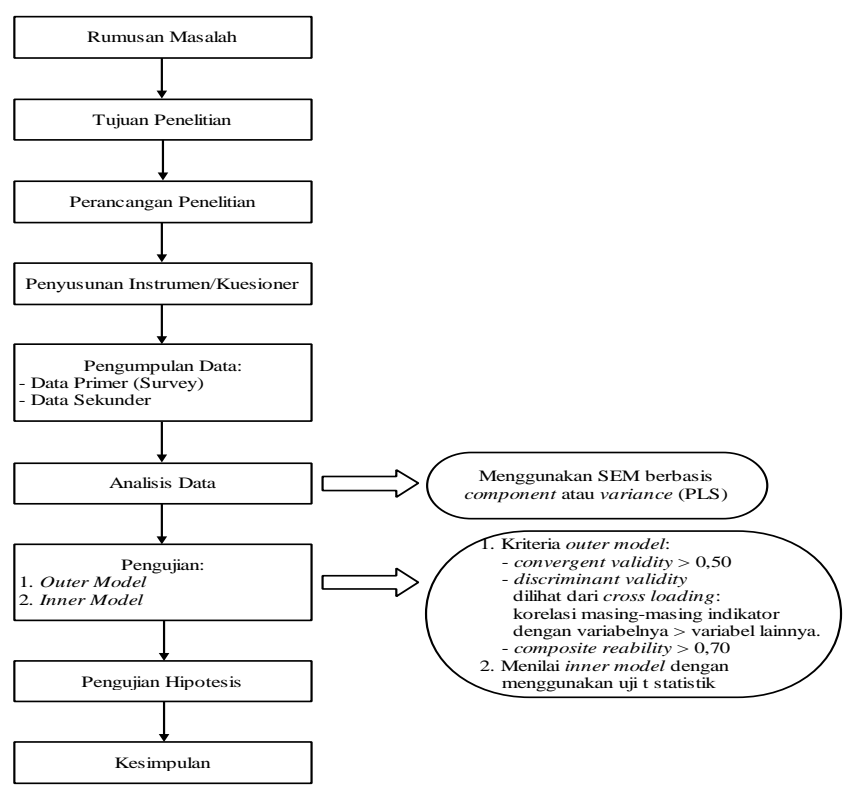

Gambar 2. Tahapan Penelitian

\section{E. Langkah-langkah Analisis Data dengan PLS}

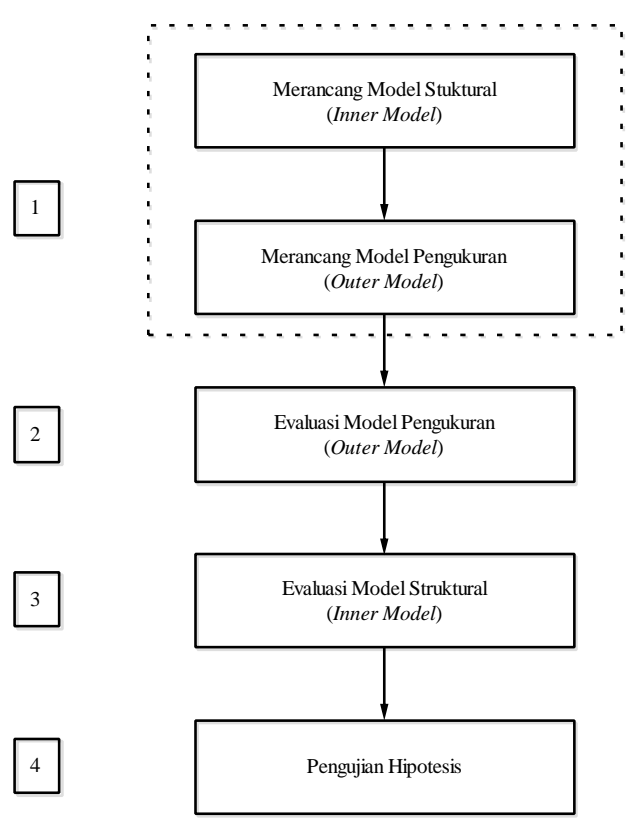

Gambar 3. Langkah-langkah Analisis Data dengan PLS 
Yuliana, Kenti \& Suhainah, Siti / LENTERA Jurnal Ilmiah Kependidikan

Vol. 14 No.2 (Juli - Desember 2019 Edisi Dies Natalis XXXIV) 147-157

\section{F. Rancangan Model Penelitian}

Rancangan model penelitian dirancang dengan menggunakan software Smart PLS, dapat diihat pada Gambar 4 dan 5.

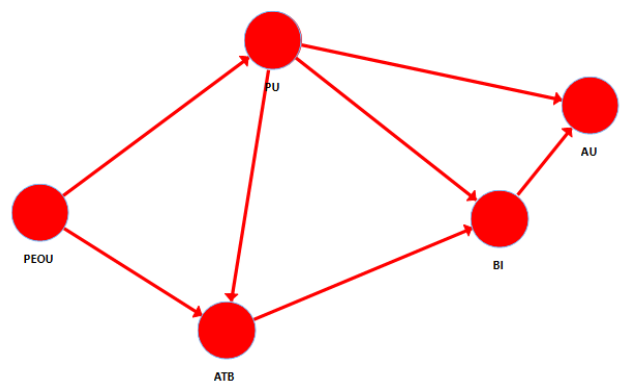

Gambar 4. Desain Model Struktural

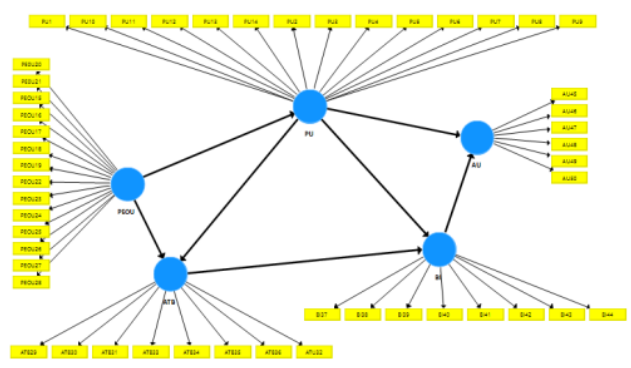

Gambar 5. Desain Model Pengukuran

\section{HASIL DAN PEMBAHASAN}

Proses evaluasi model pengukuran diawali dengan menjalankan konstruksi diagram jalur yang telah dibuat untuk mendapatkan nilai koefisien jalur dan loading. Hasil eksekusi model dapat dilihat pada Gambar 6.

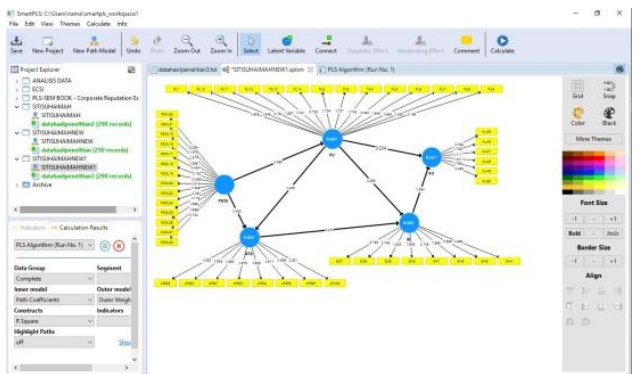

Gambar 6. Hasil Eksekusi Model Pertama

Hasil eksekusi model menujukkan bahwa ada indikator dengan loading factor di bawah 0.50 sehingga model belum dapat dievaluasi. Untuk mengevaluasi model harus dilakukan estimasi kembali dengan membuang indikator yang memiliki loading factor kurang dari 0,50. Indikator yang memiliki loading factor kurang dari 0,50 adalah PU9 (0,196), PU10 (0,346), PEOU17 (0,434), PEOU18 (0,183), PEOU19 (- 
0,068), PEOU20 (0,294), PEOU21 (0,306), PEOU23 (0,359), PEOU24 (0,481), AU48 (0,441) dan AU50 (0,493).

Setelah dihapus dilakukan kalkulasi PLS algorithm kembali. Hasil eksekusi model ke 2 dapat dilihat pada Gambar

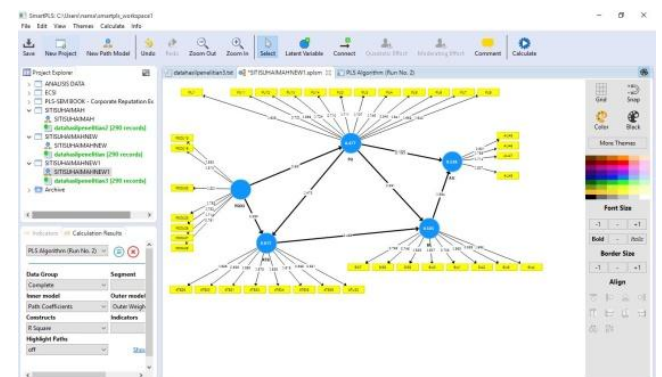

\section{Gambar 7. Hasil Eksekusi Model Kedua}

Berdasarkan gambar eksekusi model menujukkan bahwa tidak ada indikator dengan loading factor dibawah 0,50 sehingga model sudah memenuhi convergent validity.

Langkah kedua adalah menentukan discriminant validity yang dapat dilihat pada cross loading antara indikator dengan variabelnya. Output cross loading dari hasil eksekusi ke-2 dapat dilihat pada tabel 1.

Tabel 1. Output Cross Loading dari Hasil Eksekusi Kedua

\begin{tabular}{|l|l|l|l|r|l|}
\hline & ATB & AU & BI & PEOU & PU \\
\hline ATB29 & 0.826 & 0.467 & 0.544 & 0.576 & 0.612 \\
\hline ATB30 & 0.836 & 0.510 & 0.569 & 0.542 & 0.631 \\
\hline ATB31 & 0.880 & 0.466 & 0.605 & 0.622 & 0.631 \\
\hline ATB33 & 0.875 & 0.427 & 0.579 & 0.615 & 0.592 \\
\hline ATB34 & 0.838 & 0.496 & 0.587 & 0.532 & 0.603 \\
\hline ATB35 & 0.615 & 0.234 & 0.422 & 0.513 & 0.449 \\
\hline ATB36 & 0.599 & 0.337 & 0.428 & 0.520 & 0.512 \\
\hline ATB32 & 0.821 & 0.428 & 0.562 & 0.560 & 0.611 \\
\hline AU45 & 0.404 & 0.801 & 0.570 & 0.344 & 0.437 \\
\hline AU46 & 0.322 & 0.756 & 0.459 & 0.252 & 0.326 \\
\hline AU47 & 0.273 & 0.714 & 0.451 & 0.284 & 0.381 \\
\hline AU49 & 0.585 & 0.807 & 0.680 & 0.470 & 0.568 \\
\hline BI37 & 0.690 & 0.651 & 0.792 & 0.522 & 0.628 \\
\hline BI38 & 0.434 & 0.436 & 0.748 & 0.305 & 0.401 \\
\hline BI39 & 0.535 & 0.559 & 0.835 & 0.384 & 0.498 \\
\hline BI40 & 0.462 & 0.595 & 0.807 & 0.347 & 0.414 \\
\hline BI41 & 0.392 & 0.518 & 0.739 & 0.297 & 0.383 \\
\hline BI42 & 0.628 & 0.629 & 0.865 & 0.521 & 0.600 \\
\hline BI43 & 0.516 & 0.581 & 0.828 & 0.423 & 0.490 \\
\hline
\end{tabular}


Yuliana, Kenti \& Suhainah, Siti / LENTERA Jurnal Ilmiah Kependidikan

Vol. 14 No.2 (Juli - Desember 2019 Edisi Dies Natalis XXXIV) 147-157

\begin{tabular}{|l|l|l|l|r|l|}
\hline & ATB & AU & BI & PEOU & PU \\
\hline BI44 & 0.571 & 0.513 & 0.693 & 0.465 & 0.528 \\
\hline PEOU15 & 0.334 & 0.164 & 0.225 & 0.553 & 0.287 \\
\hline PEOU16 & 0.358 & 0.096 & 0.235 & 0.513 & 0.323 \\
\hline PEOU22 & 0.343 & 0.261 & 0.206 & 0.521 & 0.334 \\
\hline PEOU25 & 0.484 & 0.368 & 0.379 & 0.783 & 0.497 \\
\hline PEOU26 & 0.469 & 0.259 & 0.315 & 0.752 & 0.437 \\
\hline PEOU27 & 0.568 & 0.403 & 0.470 & 0.714 & 0.608 \\
\hline PEOU28 & 0.624 & 0.430 & 0.496 & 0.761 & 0.592 \\
\hline PU1 & 0.477 & 0.246 & 0.305 & 0.484 & 0.608 \\
\hline PU11 & 0.589 & 0.528 & 0.571 & 0.462 & 0.720 \\
\hline PU12 & 0.512 & 0.414 & 0.458 & 0.530 & 0.669 \\
\hline PU13 & 0.538 & 0.413 & 0.444 & 0.592 & 0.724 \\
\hline PU14 & 0.509 & 0.410 & 0.421 & 0.589 & 0.710 \\
\hline PU2 & 0.514 & 0.387 & 0.506 & 0.456 & 0.711 \\
\hline PU3 & 0.542 & 0.411 & 0.437 & 0.383 & 0.707 \\
\hline PU4 & 0.594 & 0.449 & 0.503 & 0.479 & 0.746 \\
\hline PU5 & 0.324 & 0.297 & 0.263 & 0.307 & 0.548 \\
\hline PU6 & 0.392 & 0.304 & 0.361 & 0.407 & 0.641 \\
\hline PU7 & 0.483 & 0.326 & 0.432 & 0.443 & 0.669 \\
\hline PU8 & 0.420 & 0.388 & 0.363 & 0.423 & 0.640 \\
\hline
\end{tabular}

Berdasarkan output cross loading dapat dilihat bahwa korelasi masing-masing indikator dengan variabelnya lebih tinggi daripada dengan variabel lain. Hal ini menunjukkan bahwa konstruk laten memprediksi indikator pada bloknya sendiri lebih baik dibandingkan dengan indikator di blok lain, sehingga dapat disimpulkan bahwa semua konstruk dalam model yang di estimasi memenuhi kriteria discriminant validity.

Langkah ketiga adalah menentukan composite reability dengan mengukur dua kriteria yaitu composite reliability dan cronbach alpha dari blok indikator yang mengukur konstruk. Konstruk dinyatakan reliable jika nilai composite reliability maupun cronbach alpha di atas 0,70 [6]. Output composite reliability dan cronbach alpha dari hasil eksekusi ke-2 dapat dilihat pada tabel 2 dan tabel 3.

Tabel 2. Output Composite Reability

\begin{tabular}{|l|r|}
\hline & $\begin{array}{c}\text { Composite } \\
\text { Reability }\end{array}$ \\
\hline ATB & 0.930 \\
\hline AU & 0.854 \\
\hline BI & 0.930 \\
\hline PEOU & 0.844 \\
\hline PU & 0.910 \\
\hline
\end{tabular}

Tabel 3. Output Cronbach Alpha 


\begin{tabular}{|l|r|}
\hline & $\begin{array}{c}\text { Cronbach's } \\
\text { Alpha }\end{array}$ \\
\hline ATB & 0.912 \\
\hline AU & 0.775 \\
\hline BI & 0.913 \\
\hline PEOU & 0.787 \\
\hline PU & 0.892 \\
\hline
\end{tabular}

Berdasarkan tabel 2 dan tabel 3 diketahui bahwa nilai composite reliability dan cronbach alpha masing-masing konstruk sudah di atas 0,70. Jadi, dapat disimpulkan bahwa masing-masing konstruk sudah memiliki reabilitas yang baik.

Setelah melakukan evaluasi model pengukuran (measurement) model, selanjutnya dilakukan evaluasi model struktural atau inner model yang dilakukan dengan melihat nilai $R$-square. Dengan metode bootstrap, peneliti dapat menilai adanya pengaruh pada model penelitian dengan menguji hipotesis untuk jalur hubungan. Tingkat signifikan yang digunakan dalam penelitian ini adalah 5\%, dengan nilai $\mathrm{t}_{\text {tabe1 }} 1,96$ yang di dapatkan dari proses bootstrapping yang berasusmi memiliki Derajat Kebebasan (DK) sebesar 500, $\mathrm{t}_{\text {tabel }}$ tersaji pada lampiran 10. Output koefisien jalur dari hasil eksekusi bootstrapping dapat dilihat pada Tabel 4.

Tabel 4. Output Koefisien Jalur

\begin{tabular}{|c|c|c|c|}
\hline & $\begin{array}{l}\text { Original } \\
\text { Sample } \\
(\mathrm{O})\end{array}$ & $\begin{array}{l}\text { T Statistics } \\
\text { (|O/STDEV|) }\end{array}$ & Keterangan \\
\hline $\begin{array}{l}\text { PEOU } \\
->\text { PU }\end{array}$ & 0.691 & 17.684 & $\begin{array}{l}\text { H1 } \\
\text { diterima }\end{array}$ \\
\hline $\begin{array}{l}\text { PEOU } \\
-> \\
\text { ATB }\end{array}$ & 0.380 & 7.056 & $\begin{array}{l}\mathrm{H} 2 \\
\text { diterima }\end{array}$ \\
\hline $\begin{array}{l}\text { PU -> } \\
\text { ATB }\end{array}$ & 0.473 & 9.172 & $\begin{array}{l}\text { H3 } \\
\text { diterima }\end{array}$ \\
\hline $\begin{array}{l}\text { PU -> } \\
\text { BI }\end{array}$ & 0.291 & 4.379 & $\begin{array}{l}\text { H4 } \\
\text { diterima }\end{array}$ \\
\hline $\begin{array}{l}\text { PU -> } \\
\text { AU }\end{array}$ & 0.195 & 3.850 & $\begin{array}{l}\text { H5 } \\
\text { diterima }\end{array}$ \\
\hline $\begin{array}{l}\text { ATB - } \\
>\text { BI }\end{array}$ & 0.468 & 6.822 & $\begin{array}{l}\text { H6 } \\
\text { diterima }\end{array}$ \\
\hline $\begin{array}{l}\text { BI -> } \\
A U\end{array}$ & 0.594 & 13.037 & $\begin{array}{l}\text { H7 } \\
\text { diterima }\end{array}$ \\
\hline
\end{tabular}




\section{KESIMPULAN}

Berdasarkan analisis hasil penelitian dan pembahasan pada bagian sebelumnya, maka dapat disimpulkan sebagai berikut.

1. Konstruk kemudahan penggunaan persepsian (perceived ease of use) berpengaruh terhadap konstruk kegunaan persepsian (perceived usefulness) dalam penerimaan Computer Based Test (CBT) sebesar 69\%.

2. Konstruk kemudahan penggunaan persepsian (perceived ease of use) berpengaruh terhadap konstruk sikap terhadap perilaku (attitude towards behavior) dalam penerimaan Computer Based Test (CBT) sebesar 38\%.

3. Konstruk kegunaan persepsian (perceived usefulness) berpengaruh terhadap konstruk sikap terhadap perilaku (attitude towards behavior) dalam penerimaan Computer Based Test (CBT) sebesar $47 \%$.

4. Konstruk kegunaan persepsian (perceived usefulness) berpengaruh terhadap konstruk minat perilaku (behavioral intention) dalam penerimaan Computer Based Test (CBT) sebesar 29\%.

5. Konstruk kegunaan persepsian (perceived usefulness) berpengaruh terhadap konstruk penggunaan sesungguhnya (actual use) dalam penerimaan Computer Based Test (CBT) sebesar 19\%.

6. Konstruk sikap terhadap perilaku (attitude towards behavior) berpengaruh terhadap konstruk minat perilaku (behavioral intention) dalam penerimaan Computer Based Test (CBT) sebesar 46\%.

7. Konstruk minat perilaku (behavioral intention) berpengaruh terhadap konstruk penggunaan sesungguhnya (actual use) dalam penerimaan Computer Based Test (CBT) sebesar 59\%.

\section{DAFTAR RUJUKAN}

Adriansyah, Novli, dkk. (2016). Analisa Penerimaan dan Penggunaan Teknologi Informasi E-Vote Menggunakan Technology Acceptance Model (TAM). Jurnal Rekayasa dan Manajemen Sistem Informasi, Vol. 2, No. 2, ISSN: 2460-8181.

Arifin, Zainal. (2014). Penelitian Pendidikan: Metode dan Paradigma Baru. Bandung: Remaja Rosdakarya.

Davis, Fred D. (1989). Perceived Usefulness, Perceived Ease of Use, and User Acceptance of Information Technology. MIS Quarterly.

Davis, Fred D. (1986). A Technology Acceptance Model for Empirically Testing New End-User Information System.Massachusetts Institute of Technology: Wayne State University.

Gardner, Christina \& Amroso, Donald L. (2004). Development of an Instrument to Measure the Acceptance of Internet Technology by Consumers. Proceedings of the $37^{\text {th }}$ Hawaii International Conference on System Sciences.

Ghozali, Imam. (2014). Stuctural Equation Modeling Metode Alternatif Dengan Partial Least Squares (PLS) Dilengkapi Software Smartpls 3.0. Xlstat 2014 dan WarpPLS 4.0. Semarang: Badan Penerbit-Undip.

Hartono, Jogiyanto. (2007). Sistem Informasi Keperilakuan. Yogyakarta: CV Andi Offset. 
Jihad, Asep \& Haris, Abdul. (2013). Evaluasi Pembelajaran. Yogyakarta: Multi Pressindo.

Kurniasari, Dewi. \& Isnani, Gatot. (2015). Analisis Pelaksanaan Kerjasama SMK dengan Dunia Usaha. Jurnal Pendidikan Bisnis dan Manajemen, Volume 1, Nomor 1, Hal (1-70).

Pakpahan, Rogers. (2016). Model Ujian Nasional Berbasis Komputer: Manfaat Dan Tantangan Computer-Based National Exam Model: Its Benefit And Barries. Jurnal Pendidikan dan Kebudayaan. Vol. 1, Nomor 1.

Riskadewi, Elsa Suryana. Penerimaan Sistem Informasi Akademik Universitas Airlangga Cyber Campus (UACC) Pada Dosen FISIP Universitas Airlangga.

Rosdiana. (2015). Teknologi Pembelajaran Berbasis ICT (Penerapan Computer Based Test. Al-Khwarizmi, Volume III, Edisi 2, Hal 31-38.

Salam, Rudi. (2013). Evaluasi Pelaksanaan Program SMK Kelas Jauh Di MAN Karanganyar. Jurnal Pendidikan Vokasi, Vol 3, Nomor 2.

Saputera, Surya Ade, dkk. (2017). Analisis Penerimaan Sistem E-Learning Menggunakan Technology Acceptance Model (TAM). Jurnal Informasi Interaktif. Vol. 2, No. 2, ISSN: 2527-5240.

Siregar, Syofian. (2017). Statistik Parametrik Untuk Penelitian Kuantitatif Di Lengkapi Dengan Perhitungan Manual Dan Aplikasi SPSS Versi 17. Jakarta: PT Bumi Aksara.

Sugiyono. (2015). Metode Penelitian Pendidikan (Pendekatan Kuantitatif, Kualitatif, dan $R \& D)$. Bandung: Alfabeta.

Sukasna, dkk, (2016). Evaluasi Penerimaan Pengguna Computer Based Test Dengan Pendekatan TAM di Kulon Progo. Jurnal Ilmiah Multitek. Vol. 10, No.2, ISSN: 1907-6223.

Taylor, Shirley \& Todd, Peter A. (1995). Understanding Information Technology Usage: A Test of Competing Models.

Wahono. (2014). Kualitas Pembelajaran Siswa SMK Ditinjau Dari Fasilitas Belajar. Jurnal Ilmiah Guru “COPE”, No. 01.

Yulianto, Ardhian Agung, dkk. (2009). Analisis dan Desain Sistem Informasi. Bandung: Politeknik Telkom. 